\title{
Economic Empowerment of Rural Women through Mushroom Farming
}

\author{
$\operatorname{Aditya}^{1}$ and J. N. Bhatia ${ }^{2 *}$ \\ ${ }^{1}$ Department of Plant Pathology, College of Horticulture and Forestry, \\ Dr. Y S Parmar University of Horticulture and Forestry, Neri (Hamirpur) HP. \\ ${ }^{2}$ CCS HAU Krishi Vigyan Kendra, Kurukshetra, Haryana, India \\ *Corresponding author
}

\section{A B S T R A C T}

\section{Keywords}

Economic empowerment, Enterprise, Mushroom, Rural women

\section{Article Info}

Accepted:

18 May 2020 Available Online: 10 June 2020
Empowerment of women and gender equality recognized globally as a key element to achieve progress in all areas since they are multifaceted, multidimensional and multilayered concept. Women constitute almost half of the total population of the world and out of this two third of world adult illiterates are women. Entrepreneurship development and income generating activities are a feasible solution for empowering women. Suitable enterprises of women will not only enable them to get better jobs and in becoming economically self reliant and independent but society will also be benefitted. In the present era, mushroom farming is a profitable enterprise since per unit productivity of mushroom is several folds high than any other crop. The enterprise apart from solving the malnutrition problem also pave the way of self employment opportunity to about $66 \%$ of the female population living in the rural sector which is idle and unutilized. One of the greatest advantage of this venture is the fact that mushroom have capacity to convert nutritionally value less substances such as wheat and rice straw into nutritional delicacies. Recognizing nutritional and medicinal value, productivity and profitability; mushroom farming has been identified as a profitable enterprise which can lead to integrate rural development by increasing the income and self employment. Krishi Vigyan Kendra Kurukshetra established under the aegis of CCS HAU Hisar is playing a pivot role in economic empowerment particularly for small farmers, farm women, landless laborers by organizing skill oriented trainings and establishment of small enterprises which in turn would improve quality of life of rural families. The results of the present study revealed that by adopting mushroom farming as a profession, there is no need to go outside home for work as sufficient work opportunity is available at home. The major constraints faced by the respondents are inadequate knowledge about mushroom practices, fluctuated prices of the mushroom in the market and lack of precooling and storage facility for the mushroom.

\section{Introduction}

Women play a significant role in Indian economy. They make critical contributions to household production and consequently to National food security. Women's role in agriculture is diffused with their diversified responsibilities in managing the household 
activities and engaging themselves in agricultural operations for saving or earning money in labour wages besides contributing in income through auxiliary occupations. Therefore a great need has been felt with consideration of substantiality and equity for exploring the possibilities of entrepreneurship development for rural women, thus enabling them to raise their standard of living and contributing their skill in nation building process.

Agriculture is the main strength of Indian economy and with variety of agricultural crops grown today. We have achieved food security by producing over 273.6 million tons of record food production. However, our struggle to achieve nutritional security is still on. Under these circumstances mushroom farming has been identified as a suitable and most profitable enterprise since per unit productivity of mushroom is several folds high than any other crop (Bhatia, and Mohammed, 2007). These are ideal tools for converting agricultural waste into protein rich non-conventional food items. Krishi Vigyan Kendras established under the aegis of CCS Haryana Agricultural University Hisar in Haryana are playing a significant role in technology assessment, refinement, front line demonstrations and transfer of technology in toto to the farmers, farm women and extension personnel in their respective districts. The major emphasis of these centres is to enhance the production and productivity as well as to generate household income and employment of rural youth through several vocations. Thus attempt was made for skill development among rural women in the field of mushroom farming so that they could start their own entrepreneurial units using low cost thatched houses. Mushroom constitutes low calorie but nutritious diet as it is rich in protein, vitamins and essentials minerals and hence they are considered as a best food for patients having diabetes, hypertension, heart attack, obesity, anaemia, cancer and constipation etc. Hence adoption of mushroom farming apart from solving malnutrition problem in rural masses also lead to rural development by increasing income and self employment particularly among women folk who constitute $70 \%$ of total women's population (Dey et al., 2020).

\section{Materials and Methods}

The present study was undertaken to assess the gain in knowledge and skill of women trainees through training programme to analyse their perception towards the training methodology and to find the technical problems faced by the respondents during the course of mushroom production. Ambala, Kurukshetra and Yamunanagar districts of Haryana were purposively selected because of having the maximum number of women mushroom growers. Two blocks from each district having maximum mushroom growers viz. Ambala-2, Brara from Ambala district, Thanesar and Shahabad from Kurukshetra district and Radaur and Chhachhroli form Yamunanagar district were finally selected for the purpose. From these 6 blocks of the 3 districts, 20 women mushroom growers per block, who had received training, gained knowledge and upgraded their skill on mushroom cultivation from Krishi Vigyan Kendra during 2018-2020, were purposively selected for the study. A personal interview technique using structured questionnaire was used to collect the information and data. A suitable schedule consisting of various questions on the basis of lesson plan was prepared for the training programme. The gain in knowledge and skill were measured by a knowledge score developed for this purpose. Co-efficient and multiple regression design was used for analysis of data. Similarly data was also analysed using mean percentage score and ranking was done accordingly. The constraints, technological gaps/problems, 
remedies for successful entrepreneurs among the ex-trainees were also studied.

\section{Results and Discussion}

Women entrepreneur are an important part of the global quest for sustained economic development and rural progress in India. Women entrepreneurial ability has been overlooked due to the lower status of the woman in the society. Women have the potential and the skill to establish and manage the enterprises on their own. What they need is encouragement and support (Kiran, 2006). Mushroom farming is efficient means for conversion of agricultural wastes into valuable proteins and presents huge potential for generating additional income and employment to the rural folks (Madan, 1997); (Singh, et al., 2014); and (Dey et al., 2020).

The results obtained in the present study and relevant discussions have been presented under following subheads:

\section{Distribution of respondents}

To get an overview of the respondents with respect to technological gap in adoption of mushroom practices, the farm women were categorized into low level of technological gap (less than 25 percent), medium (between 25 and $30 \%$ ) and high (above $30 \%$ ) level of the technological gap as shown in Table 6. This categorization was based on the basis of mean score obtained by the respondents. It is clearly visible from the results obtained in Table-2 that women mushroom growers; technological gap score ranged between 6-20 with a mean score of 12.44 which is equal to 25.92 percent. It is certainly considerable and need to be minimized by making extensive extension efforts. Further the results also revealed that 40 per cent of the respondents fall in low category i.e. having a technological gap less than 25 per cent. About more than half of the respondents $(55.00 \%)$ having medium level of technological gap (between 25 and $30 \%$ ) and about one eighth of the respondents (12\%t) having high level of technological gap. These findings are in agreement with the results of (Bhatia, 1991); and (Dass, 1996) for other crops. The study thus indicated that 55 per cent of the respondents were having medium to high level of technological gap. This calls for a serious consideration both by mushroom scientists and growers and it needs utmost introspection.

\section{Occupational and economical motivational factors}

The data incorporated in the table 3 revealed that fairly a large number of respondents get motivated to adopt mushroom farming so as to get employment at home as there was no need to go out side in search of work (MPS 85.15) and it ranked first. To get easy employment was the next important aspect (MPS 79.40) and was ranked second. Besides this, majority of them had under taken mushroom cultivation as it can be cultivated along with household chores (MPS 62.50). They were also motivated because their family members could be utilized during the different mushroom cultivation practices (MPS 54.40). Mishra and Sinha (1983) also revealed similar motivational disportions. Further it is also emphasized that number of respondents had undertaken mushroom cultivation because of quick monetary gains (MPS 85.00) and it was ranked first. Beside this comparatively more return from mushroom cultivation (78.52) was also a chief motivational factor. Respondents were also found lured towards this vocation because of getting additional income (MPS 72.10). Along with this little monetary investment for the establishment of mushroom unit (35.40) and ranked fourth. The reason for quick monetary gain was a chief economic 
motivational factor might be that mushroom starts giving production after 18 to 25 days of spawning, one can sell it and earn within a short span of duration (Table 4).

\section{Knowledge gained by the respondents}

The results shown in our study has also clearly established that the rural women showed significant gain in knowledge when they were given training on mushroom farming aspects (Table.5). The significant result obtained seems to be due to instructional package used and the constant dialogue between the recipients and the resource persons. Though the lack of formal literacy and technical terms acted as a barrier in the dissemination of scientific information, functional knowledge even though transmitted to women in a simple language with the help of suitable media mix. The action research has provided the scope for the trainees to see through the problems and get the solution right in the training situation because the centre has undertaken various activities related to mushroom vocation. The comprehensions of the trainees kept under sharp focus and they were monitored and repeated exposures were provided wherever necessary. Mushroom production training to the rural farm women in Patna, Bihar also showed an acceptance level of 61 per cent as it aided to their economic empowerment along with an increase in their knowledge regarding the intricacies of technology which would lead them to empower the next generation of farm women (Singh, et al., 2014) and (Singh, et al., 2018).

\section{Activities undertaken}

Vocational trainings

Demonstration

Mushroom days

Exhibition

Visit to mushroom melas

Establishing and monitoring of mushroom units

Success stories

Radio talks

Literature availability on mushroom

Popularization of low cost technology

\section{Identification of subsidiary enterprises}

Mushroom farming is an agricultural activity well suited to the Haryana for varied reasons such as:

Mushroom production is an indoor activity using vertical space hence does not compete with agricultural land thus suited to small farmers, farm women and landless labourers.

Many agricultural wastes can be utilized to produce quality food and organic manure in field crops. Besides mushrooms have high biological efficiency i.e. conversion of dry substances into fresh mushroom.

It can generate self employment, alleviate poverty and improve socio economic status of women and youth in the rural areas.

It can provide nutritional security particularly for poor people through incorporating mushrooms in their diet.

Need for regular additional income.

Good demand of mushroom.

Proximity to the market. According to the official sources Sonipat district of Haryana alone sends out around 500 qt. of mushroom to Delhi every day in the season and it accounts for nearly 20 percent of Delhi market share.

\section{Extent of technological gap in adoption of mushroom}

It could be seen from table. 6 that maximum technological gap was observed in case of non availability of credit facility for mushroom cultivation $(74.5 \%)$ followed by compost preparation $(58.4 \%)$, crop management 
practices $(42.2 \%)$, casing preparation $(36.5 \%)$ and mushroom type $(38.2 \%)$. The minimum technological gap was found in spawn and spawning $(13.0 \%)$, time of cultivation $(19.3 \%)$ and harvesting, picking and grading practices $(29.2 \%)$. The minimum gap in these practices may be the result of having higher knowledge and adoption level on these practices. The higher technological gap in case of compost making, casing preparation and crop management practices may be due the reason that these cultivation practices requires skills and sufficient finances, legthy as well as cumbersome process. These observations are in conformity to the findings of (Chadha, and Sharma, 1995); and (Sarkar et al., 1995). It suggest that concerted efforts should be made to bridge these gap in compost making, casing preparation and management practices because these practices play a very vital role in increasing the productivity of the mushroom The possible reason for higher technological gap in adoption of recommended practices may be due to their inability to seek more information by less participation in extension activities, poor skill development, low level of socioeconomic status and small land holdings as well. The reasons for poor adoption by the respondents were also reported by (Tiwari, and Kapoor, 1998); (Mahapatra et al., 1997); and (Singh, 1999) in their studies however, the farmer training and regular contact with the respondents have positive and significant impact on adoption of mushroom farming technology and its acceptance as a mean of livelihood generation.

Relationship between women mushroom growers 'personal, social, economic and psychological traits and technological gap

The correlation coefficient ( $r$ value) "was worked out to know the association between personal, social, economic and psychological traits with the technological gap in adoption of mushroom cultivation practices by the women mushroom growers (Table 7). It could be seen from the results obtained that among selected independent variables of the mushroom growers; education, family education, extension contact, training received, annual income, economic motivation, scientific and risk orientation at significant and negative association with the technological gap. It implies that technological gap of the respondents decreased with each unit of the increase in their education, extension contact, annual income and scientific orientation as reported by (Bhatia, 1991); (Dass, 1996); and (Singh, \& Patel, 1988).

It can also be visualized from the content of those independent variables such as age, mass media exposure, land holding and occupation also had negative association with the technological gap but not to the extent of significant level. These observations are in conformity with the earlier findings by (Bhatia, 1991); (Dass, 1996); and (Christian et al., 2003) in some other studies.

\section{Economic analysis of the respondents}

Data on economic analysis of eight women, mushroom growers also revealed that it is a profitable enterprise. During 2018-20, Kanta Devi and Dimple Devi of Village Gail Kalan, Krishna and Nirmala of village Alhar, Rajaesh Kumari and Mehndro Devi of village Yari, Kusum Devi and Usha Rani of village Antheri in three districts of Haryana earned a net income of Rs.55140/- from 500 bags, Rs.31680/- from 200 bags, Rs.91500/- from 1000 bags, Rs.29350/- from 300 bags, Rs.46340/- from 500 bags, Rs.42400/- from 500 bags, Rs.33760/- from 300 bags, Rs.30200/- from 200 bags respectively from their mushroom units (Table 8).

The working experience with large number of growers, we have been able to assess the virtues of mushroom cultivation. The results 
and outcome further substantiated that due to adoption of this entrepreneur, their income, nutritional security, standard of living and position in the society have also improved a lot.

Mushroom cultivation is not only of economic importance but also has important role to play in integrated rural development programme by increasing income and self employment opportunities among the rural women (Bhatia, et al., 2010); (Bhatia, et al.,
2012) and (Singh, et al., 2014). This enterprise is also eco-friendly. Used compost and straw may again be utilized as organic manure, animal feed and for amendment of soil. Waste and barren land can be converted to mushroom farms. Mushroom can be even cultivated by landless labourers as it is cultivated, indoors and in additional small floor areas, the vertical space can also be utilized judiciously (Manjit and Kamal, 2012) and (Dey, et al., 2020).

Table.1 Scenario of mushroom production in Haryana

\begin{tabular}{|l|l|l|l|l|l|l|l|l|l|l|l|}
\hline Years/Particulars & $\mathbf{1 9 9 8}$ & $\mathbf{1 9 9 9}$ & $\mathbf{2 0 0 0}$ & $\mathbf{2 0 0 1}$ & $\mathbf{2 0 0 2}$ & $\mathbf{2 0 0 3}$ & $\mathbf{2 0 0 4}$ & $\mathbf{2 0 0 5}$ & $\mathbf{2 0 1 0}$ & $\mathbf{2 0 1 5}$ & $\mathbf{2 0 1 8}$ \\
\hline Production (M.Ton) & 3000 & 3500 & 5000 & 6000 & 7000 & 7500 & 7000 & 7200 & 8055 & 8750 & 11050 \\
\hline No. of units & 675 & 800 & 1000 & 1170 & 1300 & 1310 & 1277 & 1316 & 1350 & 1500 & 2120 \\
\hline Income (Lakhs) & 600 & 700 & 1250 & 1620 & 2100 & 2250 & 1990 & 2370 & 2552 & 3100 & 3700 \\
\hline No. of family engaged & 4725 & 5600 & 7000 & 8190 & 9100 & 9700 & 1947 & 9500 & 10000 & 1250 & 15478 \\
\hline
\end{tabular}

Table.2 Distribution of women mushroom growers according to the their extent of mushroom cultivation practices

\begin{tabular}{|c|c|c|c|c|}
\hline Sr. No. & Category & $\begin{array}{c}\text { Technological } \\
\text { Score }\end{array}$ & $\begin{array}{c}\text { Range in } \\
\text { Percentage }\end{array}$ & $\begin{array}{c}\text { Percentage of } \\
\text { respondents }\end{array}$ \\
\hline 1. & Low & $6-12$ & $<25$ & 40 \\
\hline 2. & Medium & $13-14$ & $25-30$ & 55 \\
\hline 3. & High & $15-20$ & $>30$ & 25 \\
\hline
\end{tabular}

Score range 6-20, Mean Technological gap score: 12.44 (25.92 percent)

Table.3 Occupational motivational factors responsible for taking mushroom cultivation as subsidiary occupation by the respondents

\begin{tabular}{|c|l|c|c|}
\hline Sr. No. & \multicolumn{1}{|c|}{ Factor } & MPS & Rank \\
\hline 1. & Easy Employment & 79.40 & II \\
\hline 2. & Family can also contribute & 54.40 & IV \\
\hline 3. & Mushroom can be cultivated along with household chores & 62.50 & III \\
\hline 4. & $\begin{array}{l}\text { No need to go outside for work as sufficient work exist at } \\
\text { home itself }\end{array}$ & 85.15 & I \\
\hline
\end{tabular}


Table.4 Economic motivational factors responsible for taking mushroom cultivation as subsidiary occupation by the respondents

\begin{tabular}{|c|l|c|c|}
\hline Sr. No. & \multicolumn{1}{|c|}{ Factor } & MPS & Rank \\
\hline 1. & Quick monetary gains & 85.00 & I \\
\hline 2. & More return as compared to other vocations & 78.52 & II \\
\hline 3. & Additional income & 72.10 & III \\
\hline $\mathbf{4 .}$ & Little monetary investment & 35.40 & IV \\
\hline
\end{tabular}

Table.5 Knowledge gained by rural women through training exposures on mushroom cultivation practices

\begin{tabular}{|c|l|c|c|c|}
\hline Sr. No. & \multicolumn{1}{|c|}{ Content } & $\begin{array}{c}\text { Mean Before } \\
\text { Exposure }\end{array}$ & $\begin{array}{c}\text { Score After } \\
\text { Exposure }\end{array}$ & 't'values \\
\hline $\mathbf{1 .}$ & Mushroom type & 2.86 & 6.06 & 23.35 \\
\hline $\mathbf{2 .}$ & Mushroom Strain & 0.28 & 1.50 & 11.99 \\
\hline $\mathbf{3 .}$ & Time of cultivation & 1.76 & 4.14 & 19.41 \\
\hline $\mathbf{4 .}$ & Compost making & 1.24 & 2.02 & 9.23 \\
\hline $\mathbf{5 .}$ & Casing preparation & 1.06 & 3.32 & 10.56 \\
\hline $\mathbf{6 .}$ & Spawn and spawning & 2.25 & 4.30 & 12.10 \\
\hline $\mathbf{7 .}$ & Nutritional value & 0.30 & 2.55 & 16.52 \\
\hline $\mathbf{8 .}$ & Disease and pest management & 0.18 & 1.35 & 11.58 \\
\hline $\mathbf{9 .}$ & Management in mushroom houses & 0.20 & 2.03 & 8.12 \\
\hline $\mathbf{1 0 .}$ & Harvesting, picking and grading & 4.22 & 5.24 & 10.18 \\
\hline $\mathbf{1 1 .}$ & Marketing aspects & 1.94 & 4.06 & 12.45 \\
\hline
\end{tabular}

Table.6 Technological gap among women mushroom growers on different practices of mushroom cultivation

\begin{tabular}{|c|l|c|c|c|}
\hline Sr. No. & \multicolumn{1}{|c|}{ Practices } & $\begin{array}{c}\text { Max } \\
\text { Score }\end{array}$ & $\begin{array}{c}\text { Mean } \\
\text { Technological } \\
\text { gap score }\end{array}$ & $\begin{array}{c}\text { Mean } \\
\text { Score } \\
(\mathbf{\%})\end{array}$ \\
\hline $\mathbf{1 .}$ & Mushroom type & 10 & 3.82 & 38.2 \\
\hline $\mathbf{2 .}$ & Time of cultivation & 3 & 0.58 & 19.3 \\
\hline $\mathbf{3 .}$ & Compost making & 5 & 2.92 & 58.4 \\
\hline $\mathbf{4 .}$ & Casing preparation & 12 & 4.38 & 36.5 \\
\hline $\mathbf{5 .}$ & Spawn and spawning & 6 & 0.78 & 13.0 \\
\hline $\mathbf{6 .}$ & Non availability of credit facility & 4 & 2.98 & 74.5 \\
\hline $\mathbf{7 .}$ & Management in mushroom houses & 4 & 1.69 & 42.2 \\
\hline $\mathbf{8 .}$ & Harvesting, picking and grading & 6 & 1.75 & 29.2 \\
\hline & Over all Score & $\mathbf{5 0}$ & $\mathbf{1 8 . 9 0}$ & \\
\hline
\end{tabular}


Table.7 Correlation Co-efficient of independent variables with the attitude of variables of mushroom women growers

\begin{tabular}{|c|c|c|}
\hline Sr. No. & Characteristics & Correlation Co-efficient "r" values \\
\hline \multirow[t]{5}{*}{1.} & \multicolumn{2}{|l|}{ Personal Characteristics } \\
\hline & Age & $0.0390 \mathrm{NS}$ \\
\hline & Education & $0.2310^{* *}$ \\
\hline & Family Education & $0.1912 *$ \\
\hline & Caste & $0.008 \mathrm{NS}$ \\
\hline \multirow[t]{4}{*}{2.} & \multicolumn{2}{|c|}{ Socio-Communication Characteristics } \\
\hline & Trainings received & $0.5750^{*}$ \\
\hline & Mass media exposure & $0.4550 *$ \\
\hline & Extension Contact & $0.4465 *$ \\
\hline \multirow[t]{4}{*}{3.} & \multicolumn{2}{|l|}{ Economic Participation } \\
\hline & Land Holding & $0.056 \mathrm{NS}$ \\
\hline & Occupation & $0.2424 *$ \\
\hline & Annual Income & $0.2147^{*}$ \\
\hline \multirow[t]{4}{*}{4.} & \multicolumn{2}{|c|}{ Psychological Characteristics } \\
\hline & Economic motivation & $0.3280^{*}$ \\
\hline & Scientific orientation & $0.6850^{*}$ \\
\hline & Risk Orientation & $0.7210^{*}$ \\
\hline
\end{tabular}

* Significance of values at $\mathrm{P}=0.05$ and 0.01 , respectively; NS = Non Significance

Table.8 Economic analysis of selected mushroom units established by Women mushroom growers during 2018-20*

\begin{tabular}{|l|c|c|c|c|c|c|c|c|}
\hline $\begin{array}{l}\text { Name of women } \\
\text { mushroom } \\
\text { grower }\end{array}$ & Kanta Devi & $\begin{array}{c}\text { Dimple } \\
\text { Devi }\end{array}$ & $\begin{array}{c}\text { Krishna } \\
\text { Devi }\end{array}$ & $\begin{array}{c}\text { Nirmala } \\
\text { Devi }\end{array}$ & $\begin{array}{c}\text { Rajesh } \\
\text { Kumari }\end{array}$ & $\begin{array}{c}\text { Mahindro } \\
\text { Devi }\end{array}$ & $\begin{array}{c}\text { Kusam } \\
\text { Devi }\end{array}$ & $\begin{array}{l}\text { Usha } \\
\text { Rani }\end{array}$ \\
\hline Age (Year) & 38 & 34 & 35 & 32 & 42 & 40 & 32 & 30 \\
\hline $\begin{array}{l}\text { Unit size (10 Kg } \\
\text { bags) }\end{array}$ & 500 & 200 & 1000 & 300 & 500 & 500 & 300 & 250 \\
\hline Production (q.) & 10.2 & 5.6 & 18.5 & 5.9 & 9.8 & 9.2 & 6.8 & 6.5 \\
\hline $\begin{array}{l}\text { Expenditure } \\
\text { (Rs.) }\end{array}$ & 28500 & 12000 & 75000 & 21200 & 35500 & 35800 & 22000 & 20500 \\
\hline Return (Rs.) & 83640 & 43680 & 166500 & 50550 & 81840 & 78200 & 55760 & 50700 \\
\hline Net Return (Rs.) & 55140 & 31680 & 91500 & 29350 & 46340 & 42400 & 33760 & 30200 \\
\hline B:C Ratio & 2.93 & 3.64 & 2.22 & 2.38 & 2.30 & 2.18 & 2.53 & 2.48 \\
\hline
\end{tabular}

*Average of two years data.

Conclusively, it is established that mushroom cultivation can be adopted as profitable agro entrepreneur by rural women successfully and it has been envisaged that due to the adoption of this venture, there was not no need to go outside home for work as sufficient employment opportunity is available at home itself. Mushroom as a nutritious food needs to be popularized. Mushroom cultivation will help in eliminating protein malnutrition 
among people primarily dependent on cereals and offer remunerative employment. Women force will get another dimension of the entrepreneurial skill among effort in direction which would lead to a better human resource development "When women move forward the family moves, the village moves and the nation moves".

\section{References}

Bhatia, J.N., Ahuja, S., and Thakral, S.K., 2010. Empowering rural women through mushroom farming- A profitable enterprise. In: Santosh Tikoo (Eds.) Professionalism in Academic Excellence Delhi. pp. 503510.

Bhatia, J.N., Chauhan, R.S., and Chahal, D., 2012. Transfer of mushroom farming technology as one of the livelihood generating activity identified in rural Haryana. Agric. Update. 7(1\&2): 8084.

Bhatia, J.N., and Mohammed, S., 2007. Technological gaps in adoption of mushroom cultivation practices in Haryana. Proc. National Conference on Environment and Livelihood Security through Resource Management in Northern India held at Chandigarh from 29-31 October, 2007.

Bhatia, R. (1991). Sugarcane cultivation: Technological gap and constraints. M.Sc. (Agri.) Thesis, COA, CCS Haryana Agriculture University, Hisar, Haryana (India).

Chadha, K.L., and Sharma, S.R., 1995. Advances in Horticulture Vol.13 mushroom. In: K.L. Chadha and S.R. Sharma (Eds.) Mushroom Research in India- History, Infrastructure and Achievement, pp. 1-33, Malhotra publishing house, New Delhi (India).

Christain, B.M., Vyas, H.U., and Patel, K.H., 2003. Adoption of IPM strategy by cotton growers. Agric.Extn.Rev. 15(2): $10-11$.

Dass, R., 1996. Sorghum production technology: Technological gap and constraints analysis with special reference to Haryana. M.Sc. (Agri.) Thesis, COA, CCS Haryana Agriculture University, Hisar, Haryana (India).

Dey, A., Patel, S., and Rashid, M., 2020. Small-scale mushroom production unit for the upliftment of rural economy and women empowerment in India: A Review. Curr. J. Appl. Sci. Technol. 39(2): 38-46.

Kiran, P., 2006. Women in rural development. Contemporary Social Policy and Practice. The Women Press, New Delhi. pp. 1-372.

Madan, M., 1997. Role of mushroom cultivation in rural development. In: Advances in biological production (Rai, R.D., Dhar, B.L., and Verma, R.L., Eds.). Proc. Indian Mushroom Conference NRCM Solan, HP (India).

Mahapartra, S.C., Dass, N., and Chattopadhyay, R.N., 1997. Transfer of mushroom farming technology as one of the livelihood generating activities in rural areas and its adoption by the farmers of South West Bengal. Proc. Indian Mushroom Conference, 1997, pp. 81, Solan (HP).

Manjit, S., and Kamal, S., 2012. Mushroom Scenario in India: Agriculture Year Book 2012. pp. 83-87.

Mishra, S.P., and Singh, B.P., 1983. An analysis of motivational disportions of farmer entrepreneurs. Indian Journal of Extension Education. 19(1): 46-50.

Sarkar, B.B., Bhattacharjee, A.K., Mukhopadhyay, K.K., Amar Dass and Chatterjee, N.G. (1995). Mushroom in Tripura. Agric. Extn. Rev. 7, 27-31.

Singh, B.D., Verma, M., Kumar, R., Gupta, P.C., and Aditya., 2018. Economic 
empowerment of rural farm women through mushroom production- A case study of Patna district. Int. J. Curr. Microbiol. Appl. Sci. 7(5): 348-351.

Singh, H., and Patel, H.N., 1988. Role of socio-economic characteristics of farmers in adoption of improved practices. Maharashtra J. Extn. Edu. 7, 263-264.

Singh, S., 1999. Technological gap and constraints in adoption of mushroom cultivation. M.Sc. (Agri.) Thesis CCS
Haryana Agriculture University, Hisar, Haryana (India).

Singh, J., Chahal, V.P., Rathee, A., and Singh, K., 2014. Economic empowerment of scheduled caste (SC) landless rural women through mushroom cultivation- A case study. Afr. J. Agric. Res. 9(52): 3811-3815.

Tiwari, S.C., and Kapoor, P., 1988. Mushroom cultivation: An economic analysis. Mittal Publications, Delhi (India).

\section{How to cite this article:}

Aditya and Bhatia, J. N. 2020. Economic Empowerment of Rural Women through Mushroom Farming. Int.J.Curr.Microbiol.App.Sci. 9(06): 1081-1089.

doi: https://doi.org/10.20546/ijcmas.2020.906.134 